\title{
Wpływ Polaków na decyzje unijne. Ocena efektywności i skuteczności oddziaływania polskich europosłów VI i VII kadencji Parlamentu Europejskiego
}

\section{Uwagi wstępne}

Przedmiotem niniejszego artykułu jest analiza potencjału reprezentantów Polski w Parlamencie Europejskim (PE) w okresie dziesięciu lat naszego członkostwa w Unii Europejskiej (UE), określenie skali wpływu polskich eurodeputowanych w PE, efektywności jego wykorzystania oraz skuteczności oddziaływania na decyzje unijne. Praca europosłów w Parlamencie Europejskim zorganizowana jest w grupach politycznych według przynależności partyjnej, a nie narodowej. Analizując literaturę przedmiotu wśród najczęściej powtarzanych argumentów na rzecz skutecznego działania na europejskiej scenie parlamentarnej, wymieniane są dwa podstawowe czynniki: przynależność do dużej grupy politycznej w PE oraz liczebność delegacji krajowej w ramach grupy. Sama liczebność delegacji narodowej jest określona traktatowo. Natomiast decyzję o obsadzie mandatów podejmują wyborcy krajowi. Następnie wybrani eurodeputowani samodzielnie rozstrzygają o przynależności do grup politycznych, kierując się preferencjami politycznymi.

Dostępna literatura oferuje liczne analizy dotyczące pracy europarlamentarzystów. Dotyczą one także aktywności i oceny koordynacji działań polskiej delegacji. Dane w tych publikacjach analizowane są przeważnie w ujęciu ilościowym. Przyjmują one charakter rankingów np. na najbardziej pracowitych posłów czy na największą ilość wystąpień na forum PE. Opracowania te mają także tę wadę, że obejmują zasięgiem analizy jedną, wybraną kadencję. Wyniki badań prowadzonych w oparciu o powyżej opisane kryteria nie odzwierciedlają w pełni złożoności zagadnienia, w szczególności związanego z działalnością merytoryczną i wpływem na decyzje unijne.

Dostrzegając tę lukę w niniejszym artykule dokonuje się weryfikacji zebranych danych stosując komparatystykę obydwu kadencji w ujęciu mieszanym, w którym analiza jakościowa uzupełnia wyniki analizy ilościowej. Komparatystyka zebranych danych dotyczy VI (lata 2004-2009) i VII (lata 2009-2014) kadencji Parlamentu Europejskiego. Ponadto zastosowano analizę decyzyjną, dzięki której uzyskane wyniki zostaną uzupełnione o problematykę jakościową obejmującą diagnozę ośrodka decyzyjnego. Badaniu nie podlegają metody budowania koalicji i bloków poparcia dla danego projektu. Triangulacja wyników jest zaletą niniejszego artykułu.

Celem jest wyjaśnienie zasad pracy i funkcjonowania PE determinujących opracowywanie strategii i realizację taktyki działania. Mechanizm działania tych zasad objaś- 
niony zostanie na przykładzie polskiej reprezentacji w PE. Na wstępie przedstawione zostaną założenia prowadzonej analizy, metodologia oraz determinanty badania efektywności i skuteczności oddziaływania polskiej reprezentacji. Następnie w celu prowadzenia badania i weryfikacji hipotezy zostaną zanalizowane dane dotyczące kadencji VI oraz oddzielnie VII Parlamentu Europejskiego.

Osiagnięcie zamierzonego planu badawczego pozwoli na udzielenie odpowiedzi na następujące pytania. Na ile istotna jest liczebność delegacji narodowej w grupie politycznej PE? Czy zgrupowanie większej liczby eurodeputowanych w ramach jednej z grup politycznych zwiększa skuteczność delegacji narodowej na forum PE? Jak duża liczebność delegacji narodowej przekłada się na zdolność przekonywania pozostałych członków tej grupy politycznej? Czy polscy reprezentanci wypracowali strategię działania i czy ją realizowali? Czy polska reprezentacja w PE potrafi skutecznie działać i wchodzić w niezbędne sojusze? Czy polska delegacja potrafiła pracować grupowo, czy są to raczej sukcesy indywidualne? Które mechanizmy wpływu są skuteczniejsze: indywidualne kontakty czy zespołowa współpraca? Co zyskaliśmy na kompromisach zawieranych w Unii Europejskiej?

Niniejsze badanie służy weryfikowaniu następującej hipotezy. Skala wpływu procentowo dużego odsetka delegacji narodowej w grupie politycznej o niewielkim znaczeniu w PE jest wysoka, ale nie przekłada się na efektywność i skuteczność oddziaływania na decyzje unijne. Większa efektywność i skuteczność reprezentacji narodowej jest w przypadku udziału procentowo niewielkiej delegacji narodowej w dużej grupie politycznej PE o dużym znaczeniu w PE.

\section{Metodologia i determinanty oceny skuteczności wpływu polskiej reprezentacji w Parlamencie Europejskim na decyzje podejmowane w UE}

W badaniu zostanie określona skala wpływu delegacji narodowej w grupie politycznej, efektywność wykorzystania polskiego potencjału w Parlamencie Europejskim oraz skuteczność oddziaływania na decyzje unijne.

Skala wpływu zostanie określona poprzez analizę przynależności polskich eurodeputowanych do grup politycznych i ich liczebności w tych grupach. Ważna jest liczebność polskiej reprezentacji $\mathrm{w}$ grupie, bowiem podstawą rozstrzygnięć o charakterze politycznym (np. dotyczących obsady kluczowych stanowisk w PE) wewnątrz grup politycznych jest system d'Hondta. W grupach politycznych, w zależności od liczby uzyskanych mandatów, tworzy się specjalny system punktów, przy wykorzystaniu którego dokonuje się podziału konkretnych stanowisk. W całym procesie dba się o zrównoważoną reprezentację dużych delegacji krajowych we wszystkich gremiach (Skulimowska, 2014, s. 1). Maksimum do osiagnięcia na skali wpływu jest uzyskanie stanowiska szefa grupy politycznej PE, które umożliwia uczestnictwo w pracach Konferencji Przewodniczących ${ }^{1}$. Jest to bardzo istotny organ polityczny PE, bowiem do jego kompetencji należy decydowanie o organizacji prac PE, planowanie prac legisla-

1 Jedynie Przewodniczący PE oraz szefowie grup politycznych współtworzą Konferencję Przewodniczących. 
cyjnych, określanie kompetencji komisji i delegacji oraz ich składu (Regulamin PE, 2014, art. 24, ust. 1 oraz art. 25) ${ }^{2}$.

Efektywność polskiej delegacji w PE zostanie zbadana poprzez obliczenie ilości obejmowanych ważnych stanowisk politycznych w PE. Prace Parlamentu Europejskiego podzielone są na dwa dwuipółletnie okresy. Po upływie pierwszego następuje wybór nowego przewodniczącego, wiceprzewodniczących, kwestorów oraz szefów komisji parlamentarnych i delegacji oraz ich zastępców. Rotacja na stanowisku przewodniczącego Parlamentu jest reguła, podczas gdy w kwestii pozostałych stanowisk skład personalny nie zawsze się zmienia. W związku z przystappieniem Bułgarii i Rumunii do UE, zmiany dokonane w styczniu 2007 r. były głębsze i dotyczyły również składu osobowego całej izby, prezydium Parlamentu oraz komisji.

Decyzja o tym, kto zajmie fotele szefów komisji oraz ich zastępców (po 4 w każdej komisji) jest uwarunkowana w głównej mierze podziałem sił politycznych w Parlamencie z uwzględnieniem sprawiedliwego podziału narodowościowego. Przed ukonstytuowaniem się komisji mają miejsce rozmowy przedstawicieli grup politycznych oraz delegacji narodowych, podczas których ustala się ,nominacje” na najważniejsze stanowiska. Jest to czas intensywnych negocjacji politycznych, ale podporządkowanych parlamentarnej arytmetyce, która pozwala zachować równowagę sił w Parlamencie (Polacy, 2007).

Wybór członków komisji następuje po wyznaczeniu kandydatów przez grupy polityczne oraz posłów niezrzeszonych. Konferencja Przewodniczących przedstawia następnie kandydatury Parlamentowi, który na swym posiedzeniu zatwierdza je w głosowaniu. Następnie komisje na pierwszym posiedzeniu wybierają ze swego grona przewodniczącego i czterech wiceprzewodniczących, którzy tworzą prezydium. Jeżeli liczba kandydatów odpowiada liczbie miejsc do obsadzenia, można dokonać wyboru przez aklamację (Polacy, 2007). Jeżeli większość polskich reprezentantów skupiona będzie w dużej grupie politycznej PE, do których zalicza się chadeków lub socjalistów, tym łatwiejsze powinno być uzyskiwanie wpływu na politykę Parlamentu.

Dla każdej grupy politycznej bardzo ważne jest nie tylko obsadzenie stanowisk przewodniczących komisji, ale także to, jaką komisję obejmie dany poseł. Niektóre z nich są bowiem uważane za bardziej prestiżowe ze względu na ich moc decyzyjną (Polacy, 2007). Tam, gdzie Parlament współdecyduje ${ }^{3}$, waga komisji wzrasta. Stąd drugim miernikiem efektywności, prócz kwestii pełnienia kluczowych funkcji w pracach Parlamentu, będzie także fakt, w których komisjach stałych pracuje najwięcej Polaków. Traktaty przewiduja ścisły podział kompetencji między państwa członkowskie i Unię. Przykładowo takie zagadnienia, jak np. polityka zagraniczna, armia, kwestie światopoglądowe, pozostają domeną państw członkowskich, to one tworzą własną politykę. Działania podejmowane z poziomu unijnego mogą mieć znaczenie symboliczne lub polityczne i służą zaznaczeniu opinii PE w danej kwestii. Nie prowadzą jednak do zasadniczych zmian prawa.

Analizie podlegać będzie zatem kwestia, do jakich komisji zgłosili się polscy europosłowie, czy uczestniczą one w unijnym procesie decyzyjnym z pełnym głosem, czy

2 Ponadto regulamin przewiduje jeszcze takie uprawnienia jak, prowadzenie bezpośrednich kontaktów z innymi instytucjami Unii Europejskiej, parlamentami narodowymi i krajami trzecimi.

${ }^{3}$ Są to polityki wymienione w Traktacie o funkcjonowaniu Unii Europejskiej, w których ustanowiono zwykłą procedurę ustawodawczą. 
tylko opiniują, bądź konsultują akty tworzonego prawa. W artykule zostanie dokonana komparatystyka danych z VI i z VII kadencji Parlamentu Europejskiego, przy uwzględnieniu liczebności polskiej delegacji w poszczególnych komisjach oraz $\mathrm{w}$ grupach politycznych. Stąd istotne jest podkreślanie przynależności do grupy politycznej eurodeputowanych zwłaszcza tych, którzy sprawują kluczowe stanowiska w PE.

Oceniając pracę europosła w Parlamencie Europejskim można przyjmować różne kryteria oceny, jak np. liczba wystąpień, interpelacji, a nawet zgłoszonych poprawek czy przygotowywanych sprawozdań (reports). Jednakże, jak już zaznaczono we wstępie analiza ilościowa ograniczać się będzie jedynie do stanu pełnionych ważnych funkcji politycznych w PE. Następnie badanie zostanie uzupełnione o analizę jakościową $\mathrm{w}$ oparciu o metodę decyzyjną. Pomocne w tym zakresie będzie skupienie uwagi na działalności posła sprawozdawcy. Sprawowanie funkcji posła sprawozdawcy ${ }^{4}$ jest gwarantem skutecznego kształtowania stanowiska PE, a zarazem także potencjałem sukcesu legislacyjnego i osiagnięcia zamierzonych celów ${ }^{5}$. Funkcja ta jest niezwykle istotna, zwłaszcza w materii, która podlega zwykłej procedurze ustawodawczej. Stąd istotny dla prowadzonego wnioskowania jest zakres merytoryczny i fakt, czy przygotowywane sprawozdania podlegają procedurze kodecyzji. Analiza ilości sprawozdań przygotowanych przez polskich eurodeputowanych będzie miernikiem skuteczności oddziaływania polskiej reprezentacji w PE na unijne decyzje.

Komisja przedmiotowo właściwa powołuje sprawozdawcę, którego głównym zadaniem jest prowadzenie sprawy na poszczególnych etapach procedury. Podstawowym jego obowiązkiem jest przygotowanie raportu na temat przekazanego Parlamentowi projektu aktu unijnego ${ }^{6}$. Sprawozdawca przedstawia komisji projekt raportu do dyskusji. Zwykle raport jest przedmiotem dyskusji także w ramach poszczególnych grup politycznych. Rolą sprawozdawcy jest także zbieranie opinii i uzgadnianie stanowiska w imieniu komisji parlamentarnej w ramach trialogu z Komisją i Radą. Następnie prezentuje efekty pracy w postaci przygotowanego projektu do głosowania na forum Parlamentu (na etapie posiedzeń plenarnych), zawierającego propozycję ogólnego podejścia do wniosku Komisji. Sprawozdawca jest również pierwszym posłem, który proponuje poprawki do wniosku Komisji (Procedura, 2012).

Przydział tej funkcji podlega zasadzie proporcjonalności. Duże grupy uzyskują częściej sprawozdania. Członkowie z mniejszych grup częściej korzystają z narzędzia towarzyszącego sprawozdaniom $\mathrm{w}$ danej sprawie $-\mathrm{z}$ kontr sprawozdania, pełniąc wówczas funkcję tzw. shadowsa ${ }^{7}$.

${ }^{4}$ Poseł sprawozdawca w PE jest odpowiedzialny za przygotowanie raportu wiodącej komisji oraz uczestniczy w spotkaniach tzw. trialogu, czynnie bierze udział w wypracowaniu porozumienia, szerzej patrz Regulamin PE.

5 Przykładem może być debata nad rozporządzeniem w sprawie napojów alkoholowych, za: M. Budzanowski, Podejmowanie decyzji w procedurze współdecydowania polskie dylematy, „Polski Przegląd Dyplomatyczny" 2008, nr 1 (41), s. 67.

6 Raport posła sprawozdawcy składa się z projektu uchwały prawodawczej w sprawie aktu oraz uzasadnienia.

7 Funkcja tzw. shadowsa - roboczy skrót z ang. shadow rapporteur, kontr sprawozdawca, bądź inaczej ,,poseł cień”, polega na koordynowaniu stanowiska jednej grupy politycznej PE w ramach komisji parlamentarnej. 
Mimo tych ograniczeń formalnych praktyka weryfikuje skuteczność podejmowanych działań, bowiem jak potwierdzają eurodeputowani, efektywność działań sprawozdawcy zależy od jego kompetencji językowych, pozwalających mu na jak najwcześniejsze zaangażowanie w negocjacje nad danym stanowiskiem politycznym oraz na prowadzenie nieformalnych rozmów (Sprawozdanie, 2010, s. 164).

\section{Potencjał wpływu Polaków w Parlamencie Europejskim VI kadencji} (2004-2009)

Po raz pierwszy kontakt bezpośredni pomiędzy naszymi parlamentarzystami a eurodeputowanymi miał miejsce w 2003 r., kiedy to Parlament Europejski wystosował stosowne zaproszenie do Sejmu i Senatu RP. W odpowiedzi została wydelegowana grupa posłów jako obserwatorów przy PE (Dariusz Senatu, 2004). Główną motywacją tego działania było umożliwienie zapoznania się przyszłych eurodeputowanych z pracami i procedurami obowiązującymi w Parlamencie Europejskim. W założeniach w chwili nabycia przez Polskę pełnych praw członkowskich, do czasu przeprowadzenia wyborów powszechnych do PE, osoby te mogłyby bez niepotrzebnego okresu przystosowawczego włączyć się $\mathrm{w}$ pełni $\mathrm{w}$ pracę parlamentarną.

Polscy obserwatorzy pojawili się w Brukseli dokładnie rok przed przystąpieniem Polski do Unii Europejskiej, tj. 1 maja 2003 roku. Dysponowali oni prawem udziału w debatach i obserwacją pracy w komisjach parlamentarnych. Z dniem 1 maja 2004 roku stali się oni automatycznie eurodeputowanymi. Funkcję tę pełnili do 19 lipca 2004 roku, kiedy to zebrało się pierwsze posiedzenie nowo wybranego Parlamentu Europejskiego.

Bilans pobytu polskich delegatów nie jest jednoznaczny. Z pewnością ich działania były ograniczone zakresem przysługujących im praw. Brak czynnego udziału, jak chociażby kierowanie pracą komisji czy prawo do głosowania, najbardziej zawężał ich potencjalne możliwości. $Z$ drugiej jednak strony zaangażowanie pojedynczych posłów na forum frakcji politycznych lub plenum Parlamentu nie może przesłonić wrażenia, że posłowie-obserwatorzy traktowali pobyt w Parlamencie Europejskim głównie jako miejsce ucieczki od polityki krajowej. Również cel, jakim było wdrożenie przyszłych eurodeputowanych w system pracy Parlamentu Europejskiego, nie sprawdził się. Spośród 54 obserwatorów tylko 11 zostało wybranych na następną kadencję (Obserwatorzy, 2004). Co świadczy o wysokim obciążeniu pracą w PE: odpowiedzialność, kwalifikacje oraz duża absorpcja czasu i zaangażowanie. Kilkumiesięczne doświadczenie w formie obserwacji zniechęciło niektórych polityków do ubiegania się o właściwe mandaty.

Wybory do PE odbyły się 13 czerwca 2004 roku. W Polsce wygrali kandydaci partii centro-prawicowych ${ }^{8}$. Pierwsze miejsce uzyskała Platforma Obywatelska (24,1\% głosów, co daje 15 mandatów). Na drugim miejscu była Liga Polskich Rodzin $(15,92 \%$, co

${ }^{8}$ W przeciwieństwie partie lewicowe odniosły zwycięstwo w Estonii, w Danii, we Francji, na Malcie, w Austrii i w Portugalii. Dokładne wyniki na stronach internetowych: http://www.elections2004.eu.int/ep-election/sites/pl/, 28.04.2014. 
daje 10 mandatów), a na trzecim Prawo i Sprawiedliwość (12,67\%, zdobywając 7 mandatów). Mandaty w PE uzyskały także: Samoobrona - 6, SLD-UP - 5, Unia Wolności i PSL - po 4 oraz Socjaldemokracja Polska - 3 (PAP, 2004).

Należy podkreślić, że po raz kolejny nastąpił spadek frekwencji - 20,87\%. Niską frekwencję odnotowano nie tylko w Polsce - w skali europejskiej spadła ona z 63\% w 1979 r., do 45,6\% w 2004 r. (PAP, 2004).

Na początku VI kadencji Parlamentu Europejskiego, tj. od 19 lipca 2004 roku w Sekretariacie PE pracę znalazło około 90 Polaków (nie licząc posłów i ich asystentów). Większość z nich stanowią thumacze, bez których nie mogłoby się odbyć żadne oficjalne posiedzenie. Jednak większość zadań związanych z kreacją i utrzymaniem pozytywnego wizerunku Polski oraz opinii efektywnego europolityka spoczywało na 54 europosłach z Polski, zasiadających w ławach różnych grup politycznych Parlamentu Europejskiego.

W I połowie VI kadencji PE najliczniejszą grupą była delegacja polska w EPL-ED - 19 posłów, następnie we frakcji Niepodległość/Demokracja - 10 posłów, w PES -8 posłów, UEN -7, ALDE -4 . Kilku posłów nie zdecydowało się przystąpić do żadnej z grup politycznych (Polacy, 2007).

W połowie kadencji rozkład ilościowy polskich deputowanych w ramach grup politycznych uległ pewnym zmianom. Z najliczniejszej polskiej delegacji z grupy chrześcijańsko-demokratycznej odeszły 4 osoby i przeszły do grup UEN oraz ALDE.

Do eurosceptycznej grupy Unii na Rzecz Europy Narodów (UEN) na początku 2006 roku dołączyło 3 eurodeputowanych PSL, którzy wcześniej zasiadali w ławach EPL-ED. Do grupy tej przystapiło także kilku posłów z grupy IND/DEM oraz kilku niezrzeszonych. Stąd polska delegacja w UEN zaczęła liczyć 20 eurodeputowanych i stała się najliczniejszą delegacją narodową w tej grupie. Wśród jej członków dominowali reprezentanci wybrani z ramienia PiS (7 członków), Samoobrony (5 członków) oraz PSL (3 osoby). Dodatkowo grupa UEN stała się czwartą najliczniejszą siłą polityczną w PE (Polacy, 2007). W I połowie kadencji grupa polska stanowiła w UEN drugą pod względem wielkości, zaraz po Włochach, delegację narodową. Ta zmiana układu sił oraz samo wzmocnienie grupy spowodowało, że wywalczono stanowisko przewodniczącego Komisji Petycji dla Marcina Libickiego. Należy skonstatować, iż potencjalna siła polskiej delegacji ograniczona została relatywnie małym znaczeniem samej grupy politycznej.

W najliczniejszej frakcji Parlamentu Europejskiego - EPL-ED, zasiadało w I połowie 19 polskich europosłów, a w II - 15. Z tego 14 było członkiem Platformy Obywatelskiej a jeden - Polskiego Stronnictwa Ludowego. Nie była to licząca się reprezentacja, tym niemniej wśród tych osób aż cztery piastowały ważne funkcje $\mathrm{z}$ wyboru.

Pierwszą z nich był szef połączonej polskiej delegacji w grupie EPL-ED - Jacek Saryusz-Wolski. Na pierwszą połowę kadencji został on równocześnie wiceprzewodniczącym Parlamentu Europejskiego i członkiem biura EPL-ED. Następnie zrezygnował z pełnienia tych funkcji na rzecz objęcia przewodnictwa w Komisji Spraw Zagranicznych (AFET).

Drugim wpływowym politykiem był Janusz Lewandowski. W VI kadencji PE pełnił funkcję przewodniczącego znaczącej dla Polski - Komisji Budżetowej. Jednak po wyborze Polaka na przewodniczącego Komisji Spraw Zagranicznych (AFET) ze względów parytetowych i równowagi geograficznej przejął funkcję wiceszefa tej komi- 
sji. Pozostałe dwa stanowiska wiceprzewodniczących pełnili: Jan Olbrycht - Komisja Rozwoju Regionalnego oraz Janusz Wojciechowski - Komisja Rolnictwa i Rozwoju Wsi. Jednak ten ostatni przeszedł w 2006 r. do frakcji Unia na Rzecz Europy Narodów. Wówczas w drugiej połowie kadencji ta grupa polityczna wystawiła jego kandydaturę na to samo stanowisko, więc nie przestał wówczas pełnić powierzonej funkcji.

Kolejną pod względem ilościowym polską siłą w Parlamencie Europejskim VI kadencji byli eurodeputowani z Grupy Socjalistycznej w Parlamencie Europejskim $(\mathrm{PES})^{9}$. Czynnikiem niesprzyjającym powstaniu silnej i zwartej grupy działającej wspólnie w polskim interesie był fakt, że nie pochodzili oni z jednego środowiska politycznego. Byli wśród nich przedstawiciele Samoobrony, SLD, SdPL, UP oraz osoby niepartyjne. Dodatkowo każdy z nich był w odmienny sposób związany ze swoją partią macierzystą. Relatywna słabość grupy polskich reprezentantów w PES wiązała się głównie z rozbiciem wewnątrz delegacji oraz często występującym brakiem konsolidacji wysiłków na rzecz stworzenia i realizacji wspólnego planu. Mimo to fakt, iż polska grupa była we frakcji PES jedną z liczniejszych, odwzorowany został w kwestii piastowanych funkcji w strukturach Parlamentu Europejskiego. Z grupy 9 polskich eurodeputowanych znaczące stanowiska zajmowało pięć osób. Przewodniczącego polskiej grupy w PES Marka Siwca wybrano w drugiej połowie kadencji na wiceprzewodniczącego Parlamentu Europejskiego. Ponadto stanowiska wiceprzewodniczących zajmowali: Lidia Geringer de Oedenberg - Komisja Prawna, Bogusław Liberadzki - Komisja Kontroli Budżetowej oraz Józef Pinior - Podkomisja Praw Człowieka. Natomiast w pierwszej połowie kadencji Genowefa Grabowska piastowała funkcję Kwestora PE, a Andrzej Szejna był wiceprzewodniczącym Komisji Prawnej.

Na początku VI kadencji PE w grupie politycznej współtworzonej przez Ligę Polskich Rodzin występował najwyższy odsetek polskich eurodeputowanych. Dziesięciu europosłów zasiadło wraz z UK Independance Party, która również wprowadziła do PE 10 posłów, w ławach grupy politycznej Niepodległość/Demokracja (IND/DEM). Jednak siła polityczna posłów LPR ograniczała się głównie do głośnych medialnie akcji, które w żaden sposób nie przekładały się na skuteczność oddziaływania politycznego w Unii Europejskiej. Jedynie Sylwester Chruszcz z LPR był w pierwszej połowie kadencji PE wiceprzewodniczącym Komisji Transportu i Turystyki. Parlament Europejski w sposób ,naturalny” stara się ograniczać wpływy partii otwarcie antyeuropejskich, ale również przyczynia się do tego wewnętrzne rozbicie oraz świadoma marginalizacja posłów LPR (Giertych, 2005). Potwierdzeniem tego jest fakt, że frakcja ID nie wybrała na swojego reprezentanta jednego z członków LPR, choć stanowili oni najliczniejszą grupę we frakcji ID. Siła polityczna tej grupy polskich europosłów uległa dalszemu osłabieniu po przejściu trzech z nich do grupy „niezrzeszonych”.

W wyraźnym kontraście do wyżej opisanej grupy stali reprezentanci z ramienia Partii Demokratycznej - demokraci.pl. Zasiadali oni w ławach trzeciej co do wielkości grupy w Parlamencie - Grupa Porozumienia Liberałów i Demokratów na rzecz Europy (ALDE). Chociaż było to zaledwie pięciu reprezentantów w liczącej 90 osób frakcji, to były to osoby znane i cenione wśród europejskich elit politycznych: Bronisław Gere-

9 Szerzej http://www.pespolska.pl, 28.04.2014. 
mek, Jan Kułakowski, Paweł Piskorski, Janusz Onyszkiewicz i Grażyna Staniszewska. I osobowość i profesjonalizm pozwolił obsadzić stanowisko wiceprzewodniczącego Parlamentu Europejskiego, które w pierwszej połowie kadencji piastował Janusz Onyszkiewicz. Warto dodać, iż z tej grupy Bronisław Geremek był kandydatem na stanowisko Przewodniczącego Parlamentu Europejskiego, lecz w głosowaniu zebrał drugą co do ilości liczbę głosów.

Najmniej widoczni i mało wpływowi w Parlamencie Europejskim VI kadencji byli eurodeputowani Samoobrony. Spośród 6 mandatów w I połowie kadencji dwa wzmacniały Grupę Socjalistyczną w PE (PES). Pozostali czterej europosłowie działali jako niezrzeszeni. Jednakże w drugiej połowie kadencji pięciu posłów Samoobrony współtworzyło grupę polityczną UEN.

Tabela 1

Polscy eurodeputowani w grupach politycznych Parlamentu Europejskiego

\begin{tabular}{|c|c|c|c|c|c|}
\hline $\begin{array}{c}\text { Nazwa grupy politycznej PE } \\
\text { i ilość mandatów }\end{array}$ & $\begin{array}{l}\text { Ilość } \\
\text { polskich } \\
\text { eurode- } \\
\text { putowa- } \\
\text { nych }\end{array}$ & \begin{tabular}{|} 
Przynależność \\
partyjna \\
w kraju
\end{tabular} & \multirow[t]{2}{*}{$\begin{array}{c}\text { Nazwa grupy politycznej PE } \\
\text { i ilość mandatów }\end{array}$} & $\begin{array}{l}\text { Ilość } \\
\text { polskich } \\
\text { eurode- } \\
\text { putowa- } \\
\text { nych }\end{array}$ & $\begin{array}{l}\text { Przyna- } \\
\text { leżność } \\
\text { partyjna } \\
\text { w kraju }\end{array}$ \\
\hline & \multicolumn{2}{|c|}{$\begin{array}{l}\text { VI kadencji } \\
(2004-2009)\end{array}$} & & \multicolumn{2}{|c|}{$\begin{array}{l}\text { VII kadencji } \\
(2009-2014)\end{array}$} \\
\hline $\begin{array}{l}\text { EPL-ED: Grupa Europejskiej } \\
\text { Partii Ludowej (Chrześcijań- } \\
\text { scy Demokraci) i Europejskich } \\
\text { Demokratów - } 289\end{array}$ & 15 & PO i PSL & $\begin{array}{l}\text { EPL: Grupa Europejskiej Par- } \\
\text { tii Ludowej (Chrześcijańscy } \\
\text { Demokraci) }-274\end{array}$ & 29 & PO i PSL \\
\hline $\begin{array}{l}\text { PES: Grupa Socjalistyczna } \\
\text { w Parlamencie Europejskim } \\
-214\end{array}$ & 9 & $\begin{array}{l}\text { SLD-UP, } \\
\text { SdRP, Samo- } \\
\text { obrona }\end{array}$ & $\begin{array}{l}\text { S\&D: Grupa Postępowego So- } \\
\text { juszu Socjalistów i Demokra- } \\
\text { tów w Parlamencie Europej- } \\
\text { skim - } 196\end{array}$ & 7 & SLD-UP \\
\hline $\begin{array}{l}\text { ALDE: Grupa Porozumienia } \\
\text { Liberałów i Demokratów na } \\
\text { rzecz Europy }-100\end{array}$ & 5 & $\begin{array}{l}\text { UW/Demokra- } \\
\text { ci i PO }\end{array}$ & $\begin{array}{l}\text { ALDE: Grupa Porozumienia } \\
\text { Liberałów i Demokratów na } \\
\text { rzecz Europy }-83\end{array}$ & - & \\
\hline $\begin{array}{l}\text { UEN: Grupa Unii na rzecz Eu- } \\
\text { ropy Narodów - } 44\end{array}$ & 20 & $\begin{array}{l}\text { PiS, Samoobro- } \\
\text { na, PSL, LPR, } \\
\text { Forum Polskie } \\
\text { i bezpartyjni }\end{array}$ & $\begin{array}{l}\text { EKR: Europejscy Konserwa- } \\
\text { tyści i Reformatorzy - } 57\end{array}$ & 11 & PiS i PO \\
\hline $\begin{array}{l}\text { GREENS/EFA: Grupa Zielo- } \\
\text { nych/Wolne Przymierze Euro- } \\
\text { pejskie }-43\end{array}$ & - & & $\begin{array}{l}\text { GREENS/EFA: Grupa Zielo- } \\
\text { nych/Wolne Przymierze Euro- } \\
\text { pejskie }-57\end{array}$ & - & \\
\hline $\begin{array}{l}\text { GUE/NGL: Konfederacyjna } \\
\text { Grupa Zjednoczonej Lewicy } \\
\text { Europejskiej-Nordycka Zielo- } \\
\text { na Lewica }-41\end{array}$ & - & & $\begin{array}{l}\text { GUE/NGL: Konfederacyjna } \\
\text { Grupa Zjednoczonej Lewicy } \\
\text { Europejskiej-Nordycka Zielo- } \\
\text { na Lewica - } 35\end{array}$ & - & \\
\hline $\begin{array}{l}\text { IND/DEM: Grupa Niepodle- } \\
\text { głość/Demokracja }-22\end{array}$ & 2 & LPR & $\begin{array}{l}\text { EFD: Grupa Europy Wolności } \\
\text { i Demokracji Bezpośredniej-31 }\end{array}$ & 4 & PiS \\
\hline NI: Niezrzeszeni - 28 & 3 & LPR & NI: Niezrzeszeni - 33 & - & \\
\hline
\end{tabular}

Źródło: Zestawienie własne na podstawie danych podawanych na oficjalnych stronach internetowych Parlamentu Europejskiego m.in. http://www.europarl.europa.eu/meps/pl/crosstable.html oraz http://www.europarl.europa.eu/aboutparliament/pl/004a50d310/Sk\%C5\%82ad-Parlamentu-Europejskiego.html, 27.03.2014. 
W przedmiotowej analizie ważnym czynnikiem jest rozkład ilościowy polskich europosłów w komisjach parlamentarnych. Liczną reprezentację mieliśmy w komisjach znaczących dla unijnego procesu decyzyjnego: po pięciu w Komisji Rozwoju Regionalnego (REGI) oraz Rolnictwa i Rozwoju Wsi (AGRI), czterech w Komisji Transportu i Turystyki (TRAN), trzech w Komisji Rynku Wewnętrznego i Ochrony Konsumentów.

Najliczniejszą reprezentację mieliśmy w Komisji Spraw Zagranicznych (AFET) - aż 10 eurodeputowanych. Jest to komisja, w której PE nie proceduje na równych prawach z Radą w tzw. procedurze kodecyzji. Podobnie jest w przypadku Komisji Prawnej, w której mieliśmy czterech reprezentantów (Nowi członkowie, 2007).

Tabela 2

Zestawienie imienne wybranych polskich eurodeputowanych pelniących ważne funkcje organizacyjne w Parlamencie Europejskim VI kadencji (2004-2009)

\begin{tabular}{|c|c|c|}
\hline $\begin{array}{l}\text { Pelniona funkcja w I pol. lub II pol. } \\
\text { kadencji }\end{array}$ & Imię i nazwisko & Grupa polityczna w PE \\
\hline 1 & 2 & 3 \\
\hline $\begin{array}{l}\text { Wiceprzewodniczący Parlamentu Europej- } \\
\text { skiego }\end{array}$ & \multirow{2}{*}{ Jacek Saryusz-Wolski } & \multirow{2}{*}{$\begin{array}{l}\text { Grupa Europejskiej Partii Ludowej (Chrześ- } \\
\text { cijańscy Demokraci) i Europejskich Demo- } \\
\text { kratów }\end{array}$} \\
\hline $\begin{array}{l}\text { Przewodniczący Komisji Spraw Zagranicz- } \\
\text { nych }\end{array}$ & & \\
\hline $\begin{array}{l}\text { Wiceprzewodniczący Parlamentu Europej- } \\
\text { skiego }\end{array}$ & \multirow{2}{*}{ Janusz Onyszkiewicz } & \multirow[t]{2}{*}{$\begin{array}{l}\text { Porozumienie Liberałów i Demokratów na } \\
\text { rzecz Europy }\end{array}$} \\
\hline $\begin{array}{l}\text { Wiceprzewodniczący Komisji Spraw Za- } \\
\text { granicznych }\end{array}$ & & \\
\hline $\begin{array}{l}\text { Wiceprzewodniczący Parlamentu Europej- } \\
\text { skiego }\end{array}$ & Adam Bielan & Unia na rzecz Europy Narodów \\
\hline $\begin{array}{l}\text { Wiceprzewodniczący Parlamentu Europej- } \\
\text { skiego }\end{array}$ & Marek Siwiec & $\begin{array}{l}\text { Grupa Socjalistyczna w Parlamencie Euro- } \\
\text { pejskim }\end{array}$ \\
\hline Wiceprzewodnicząca Komisji Prawnej & $\begin{array}{l}\text { Lidia Geringer de } \\
\text { Oedenberg }\end{array}$ & $\begin{array}{l}\text { Grupa Socjalistyczna w Parlamencie Euro- } \\
\text { pejskim }\end{array}$ \\
\hline Przewodniczący Komisji Budżetowej & \multirow[t]{2}{*}{ Janusz Lewandowski } & \multirow{2}{*}{$\begin{array}{l}\text { Grupa Europejskiej Partii Ludowej (Chrze- } \\
\text { ścijańscy Demokraci) i Europejskich De- } \\
\text { mokratów }\end{array}$} \\
\hline Wiceprzewodniczący Komisji Budżetowej & & \\
\hline Przewodniczący Komisji Petycji & Marcin Libicki & Unia na rzecz Europy Narodów \\
\hline $\begin{array}{l}\text { Wiceprzewodniczący Komisji Transportu } \\
\text { i Turystyki }\end{array}$ & Sylwester Chruszcz & Niezrzeszeni \\
\hline Kwestor PE & $\begin{array}{l}\text { Genowefa Grabow- } \\
\text { ska }\end{array}$ & $\begin{array}{l}\text { Grupa Socjalistyczna w Parlamencie Euro- } \\
\text { pejskim }\end{array}$ \\
\hline $\begin{array}{l}\text { Wiceprzewodniczący Komisji Kontroli Bu- } \\
\text { dżetowej }\end{array}$ & Bogusław Liberadzki & $\begin{array}{l}\text { Grupa Socjalistyczna w Parlamencie Euro- } \\
\text { pejskim }\end{array}$ \\
\hline $\begin{array}{l}\text { Wiceprzewodniczący } \\
\text { Regionalnego }\end{array}$ & Jan Olbrycht & $\begin{array}{l}\text { Grupa Europejskiej Partii Ludowej (Chrze- } \\
\text { ścijańscy Demokraci) i Europejskich De- } \\
\text { mokratów }\end{array}$ \\
\hline $\begin{array}{l}\text { Wiceprzewodniczący Podkomisji Praw } \\
\text { Człowieka }\end{array}$ & Józef Pinior & $\begin{array}{l}\text { Grupa Socjalistyczna w Parlamencie Euro- } \\
\text { pejskim }\end{array}$ \\
\hline $\begin{array}{l}\text { Wiceprzewodniczący Delegacji ds. stosunków } \\
\text { ze Zgromadzeniem Parlamentarnym NATO }\end{array}$ & Piskorski Paweł & $\begin{array}{l}\text { Porozumienie Liberałów i Demokratów na } \\
\text { rzecz Europy }\end{array}$ \\
\hline
\end{tabular}




\begin{tabular}{||l|l|l||}
\hline \multicolumn{1}{|c|}{1} & \multicolumn{1}{|c||}{2} & \multicolumn{1}{|c||}{3} \\
\hline Wiceprzewodniczący Komisji Prawnej & Andrzej Szejna & $\begin{array}{l}\text { Grupa Socjalistyczna w Parlamencie Euro- } \\
\text { pejskim }\end{array}$ \\
\hline $\begin{array}{l}\text { Wiceprzewodniczący Komisji Rolnictwa } \\
\text { i Rozwoju Wsi }\end{array}$ & $\begin{array}{l}\text { Janusz Wojciechow- } \\
\text { ski }\end{array}$ & $\begin{array}{l}\text { Grupa Europejskiej Partii Ludowej (Chrześ- } \\
\text { cijańscy Demokraci) i Europejskich Demo- } \\
\text { kratów }\end{array}$ \\
\hline
\end{tabular}

Źródło: Zestawienie własne na podstawie danych podanych w Komunikacie prasowym, Polacy na stanowiskach w Parlamencie Europejskim, Dział Prasowy, Dyrekcja ds. Kontaktów z Mediami, Instytucje - Polska - 1.02.2007, na oficjalnych stronach internetowych Parlamentu Europejskiego, http:/www.europarl.europa.eu/sides/getDoc.do?pubRef=-//EP//NONSGML+IM-PRESS+20070109IPR01815+PL+DOC+PDF+V0//PL\&language=PL, 24.04.2014.

Sumując należy podkreślić, że w ramach struktury organizacyjnej VI kadencji PE aż 15 polskich eurodeputowanych wypełniało najwyższe funkcje. Na początku tej kadencji w 2004 roku dwóm Polakom przypadły stanowiska wiceprzewodniczących Parlamentu. Także dwóch deputowanych z Polski pełniło stanowiska szefów komisji, a czworo zostało wybranych na wiceprzewodniczących. Ponadto dwóch polskich deputowanych kierowało pracami delegacji jako ich przewodniczący, a czterech jako wiceprzewodniczący. Polska posłanka była także jednym z pięciorga kwestorów.

W II połowie VI kadencji PE również dwóch Polaków pełniło funkcję wiceprzewodniczących PE oraz dwóch przewodniczyło pracom komisji parlamentarnych. Ponadto sześciu reprezentantów Polski objęło stanowiska wiceprzewodniczących. Straciliśmy stanowisko kwestora PE.

W ciagu całej VI kadencji Parlamentu Europejskiego nie mieliśmy reprezentanta w Konferencji Przewodniczących, co mogłoby być ułatwieniem dla obejmowania kluczowych stanowisk politycznych. Wszelkie osiagnięcia polskich europarlamentarzystów są efektem ich pracy zespołowej. Już na początku kadencji polscy eurodeputowani z inicjatywy posłów PiS powołali do życia tzw. Klub Polski. Zalety jego funkcjonowania doceniają przedstawiciele wszystkich polskich partii reprezentowanych w PE, którzy bez wyjątku aktywnie działają w jego ramach. Comiesięczna konsultacja projektów legislacyjnych pozwala na wychwytywanie ważnych dla Polski kwestii i ustalanie wspólnej strategii działania. Wzmacnia to z pewnością siłę polskiego głosu w PE (Libicki, 2008).

Weryfikacji hipotezy służy także analiza ilości sprawozdań, przygotowanych przez polskich reprezentantów w PE. Uzyskanie funkcji posła sprawozdawcy nie jest zadaniem łatwym i wymagającym spełnienia dwóch warunków. Po pierwsze duże grupy polityczne otrzymują większą liczbę sprawozdań do podziału, a po drugie w ramach grup politycznych liczy się liczebność delegacji narodowej. W VI kadencji PE na 24 polskich eurodeputowanych, którzy sprawowali funkcję sprawozdawcy, 19 przynależało do grup EPL-ED oraz PES (Szczepanik, Kaca, Łada, 2009, s. 45). Wśród sprawozdawców nie znajdują się polscy eurosceptycy, wybrani z list LPR, którzy swoje działania koncentrowali na krytyce i kontestacji sposobu funkcjonowania UE. Można domniemywać, że byli świadomi, że propozycje zawarte w przygotowanych przez nich sprawozdaniach nie znalazłyby najprawdopodobniej poparcia większości PE (Szczepanik, Kaca, Łada, 2009, s. 46). 
Najwięcej istotnych sprawozdań przygotował Janusz Lewandowski (EPL-ED) w procedurze budżetowej. Następnie w procedurze kodecyzji sprawozdania przygotowali m. in.: Bogusław Liberadzki (PES) w Komisji Transportu i Turystyki, Dariusz Rosati (PES) w Komisji Gospodarczej i Monetarnej, Jerzy Buzek (EPL-ED) w Komisji Przemysłu, Badań Naukowych i Energii, Barbara Kudrycka (EPL-ED) w Komisji Wolności Obywatelskich, Sprawiedliwości i Spraw Wewnętrznych (Szczepanik, Kaca, Łada, 2009, s. 48 i nast.).

Pod względem ilościowym rekordzistami w VI kadencji PE byli posłanka Lidia Joanna Geringer de Oedenberg (PES) w Komisji Prawnej (JURI) ${ }^{10}$ oraz Jacek Saryusz-Wolski (EPL-ED) w Komisji Spraw Zagranicznych (AFET) ${ }^{11}$, którzy złożyli po 17 sprawozdań (Szczepanik, Kaca, Łada, 2009, s. 46). Przygotowanie sprawozdań w tych komisjach nie wiąże się ze zwiększoną pracą związaną z prowadzeniem negocjacji pomiędzy grupami politycznymi, bowiem Parlament Europejski nie dysponuje w tych dziedzinach prawem wprowadzania poprawek do opiniowanych aktów prawnych.

Zestawiając powyższe dane z informacjami dotyczącymi obsady komisji przez polskich eurodeputowanych można wnioskować, że zbieżność istnieje głównie w przypadku Komisji Spraw Zagranicznych (AFET) oraz ewentualnie Komisji Transportu i Turystyki (TRAN). W tych komisjach było dużo Polaków i przygotowano dużo sprawozdań. W pozostałych przypadkach sprawozdania przygotowano w komisjach, w których zasiadało po troje lub dwoje polskich przedstawicieli, i co istotne, byli zrzeszeni w dużych grupach politycznych: EPL-ED, PES lub UEN.

Poparcie Parlamentu Europejskiego udzielone Pomarańczowej Rewolucji na Ukrainie, zgodnie z dążeniem Polski, świadczyło o polskim potencjale w tworzeniu i prowadzeniu stosunków UE z państwami trzecimi i innymi organizacjami. Polscy reprezentanci odgrywali kluczową rolę w kształtowaniu stosunków Parlamentu Europejskiego z bliskimi sąsiadami UE. W VI kadencji PE Polacy obsadzali stanowisko przewodniczącego Delegacji Parlamentarnej UE-Ukraina oraz Delegacji Parlamentarnej ds. Stosunków z Białorusią.

Działania polskich prawicowych eurodeputowanych VI kadencji w mediach - a pośrednio w „europejskiej” opinii publicznej - łączone były głównie z kilkoma głośnymi akcjami protestacyjno-ostentacyjnymi. Kształtowały one opinię o Polsce, jako kraju $\mathrm{z}$ jednej strony konserwatywnego i agresywnego w swych postawach, $\mathrm{z}$ drugiej strony zaś nie bojącego się w jasny i bezpośredni sposób bronić swoich racji. Niestety trudno ocenić skalę skuteczności takich działań, poza PR-em, ze strony polskich parlamentarzystów. Faktem natomiast jest, że do Parlamentu VII kadencji nie zostali wybrani przedstawiciele partii eurosceptycznych, którzy w poprzedniej kadencji wyróżniali się przede wszystkim demonstracyjną niechęcią wobec integracji europejskiej.

${ }^{10}$ Do zakresu merytorycznego tej komisji należy m. in. europejskie prawo cywilne, europejskie prawo spółek, prawo administracyjne, prywatne prawo międzynarodowe, które nie należy do kompetencji Unii Europejskiej. Posłanka przygotowała 15 sprawozdań w ramach procedury kodyfikacji (art. 80 Regulaminu PE), w ramach której PE nie wprowadza do aktów prawnych żadnych poprawek merytorycznych.

${ }^{11}$ Przygotował 8 sprawozdań w procedurze konsultacji oraz 5 procedurze zgody. 


\section{Potencjal Polaków w Parlamencie Europejskim VII kadencji (2009-2014)}

W wyniku wyborów 7 czerwca 2009 r. z Polski wybrano 50 europosłów ${ }^{12}$. Najwyższe poparcie uzyskała Platforma Obywatelska z wynikiem 44,43\%, co przyniosło jej 25 mandatów. Na drugim miejscu Prawo i Sprawiedliwość osiagnęło 27,4\% poparcia - 15 mandatów. Sojusz Lewicy Demokratycznej-Unia Pracy zdobyły 12,34\% głosów, zdobywając 7 mandatów. Ostatnie trzy mandaty zdobyło Polskie Stronnictwo Ludowe z wynikiem 7\% (Wyniki, 2009). W 2011 PSL otrzymało czwarty mandat w związku z wejściem w życie Traktatu lizbońskiego.

Oczekiwania wobec wybranych europosłów VII kadencji były większe, bowiem były to przeważnie osoby posiadające doświadczenie i ważne osiagnięcia z poprzednich lat. Dwudziestu polskich przedstawicieli zostało wybranych ponownie, co stanowi ok. $40 \%$. Jest to wynik porównywalny z osiaganymi w innych państwach członkowskich (Scarrow, 1997). Najwięcej eurodeputowanych ponownie sprawujących swój mandat zostało wybranych z list Platformy Obywatelskiej (9 posłów) oraz Prawa i Sprawiedliwości (6 posłów). Natomiast 4 europosłów zostało ponownie wybranych z list koalicji Sojuszu Lewicy Demokratycznej-Unii Pracy oraz jeden reprezentujący Polskie Stronnictwo Ludowe. W trakcie kadencji liczba ta ulegała niewielkim zmianom. Doświadczenia wynikające ze sprawowania mandatu w przeszłości powinny skutkować profesjonalizacją działań, a co z tym związane wyższym poziomem aktywności parlamentarnej (Marmola, 2014, s. 8).

Zestawienie składu Parlamentu Europejskiego i przynależności europosłów do grup politycznych z tabeli 1 wskazuje, że znacznie wzrosła liczba polskiej reprezentacji w grupie EPL. Ta silna koncentracja w największej, wpływowej grupie politycznej PE, dała podstawę do skutecznego wspierania kandydatury Polaka na stanowisko przewodniczącego PE. Jerzy Buzek jako pierwszy reprezentant nowych państw członkowskich, które przystąiły do UE w 2004 r., został wybrany na przewodniczącego Parlamentu Europejskiego na I połowę kadencji PE. O sile pozycji polskiej delegacji w tej grupie świadczy fakt, że objęliśmy także stanowisko jednego z dziewięciu wiceprzewodniczących grupy, które pełnił Jacek Saryusz-Wolski. Ta silna reprezentacja pozwoliła polskiej delegacji na wywalczenie w II połowie kadencji stanowiska wiceprzewodniczącego PE dla Jacka Protasiewicza (patrz tabela 3).

Natomiast europosłowie wybrani z list PiS stworzyli nową grupę polityczną wraz z konserwatystami brytyjskimi i czeskimi pod nazwą Europejscy Konserwatyści i Reformatorzy (EKR). Michał Kamiński objął funkcję przewodniczącego tej grupy na I połowę kadencji PE. Pod koniec 2011 czterech polskich deputowanych przeszło do nowej grupy, co przyczyniło się do znacznego osłabienia polskiej delegacji w tej grupie. W wyniku automatyzmu arytmetyki parlamentarnej Polakom przypadło stanowisko wiceprzewodniczącego grupy, które objął Ryszard Legutko ${ }^{13}$.

12 Po wejściu w życie Traktatu z Lizbony Polska otrzymała dodatkowy mandat, stąd w drugiej połowie kadencji Polskę reprezentowało 51 europosłów.

13 Przewodniczącym grupy konserwatystów został Brytyjczyk Martin Callanan. 
Zestawienie imienne wybranych polskich eurodeputowanych pelniących ważne funkcje organizacyjne w Parlamencie Europejskim VII kadencji (2009-2014)

\begin{tabular}{|c|c|c|}
\hline Pelniona funkcja w I lub II pol. kadencji & Imię i nazwisko & Grupa polityczna w PE \\
\hline Przewodniczący Parlamentu Europejskiego & Jerzy Buzek & $\begin{array}{l}\text { Grupa Europejskiej Partii Ludowej (Chrześ- } \\
\text { cijańscy Demokraci) }\end{array}$ \\
\hline $\begin{array}{l}\text { Wiceprzewodniczący Parlamentu Europej- } \\
\text { skiego }\end{array}$ & Jacek Protasiewicz & $\begin{array}{l}\text { Grupa Europejskiej Partii Ludowej (Chrześ- } \\
\text { cijańscy Demokraci) }\end{array}$ \\
\hline Przewodniczący grupy politycznej EKR & Michał Kamiński & Europejscy Konserwatyści i Reformatorzy \\
\hline $\begin{array}{l}\text { Wiceprzewodniczący Komisji Kontroli Bu- } \\
\text { dżetowej }\end{array}$ & Bogusław Liberadzki & $\begin{array}{l}\text { Grupa Postępowego Sojuszu Socjalistów } \\
\text { i Demokratów }\end{array}$ \\
\hline $\begin{array}{l}\text { Przewodniczący Komisji Rozwoju Regio- } \\
\text { nalnego }\end{array}$ & Danuta Hübner & $\begin{array}{l}\text { Grupa Europejskiej Partii Ludowej (Chrześ- } \\
\text { cijańscy Demokraci) }\end{array}$ \\
\hline $\begin{array}{l}\text { Wiceprzewodniczący Komisji Rolnictwa } \\
\text { i Rozwoju Wsi }\end{array}$ & Czesław Siekierski & $\begin{array}{l}\text { Grupa Europejskiej Partii Ludowej (Chrześ- } \\
\text { cijańscy Demokraci) }\end{array}$ \\
\hline $\begin{array}{l}\text { Wiceprzewodniczący Komisji Rolnictwa } \\
\text { i Rozwoju Wsi }\end{array}$ & $\begin{array}{l}\text { Janusz Wojciechow- } \\
\text { ski }\end{array}$ & Europejscy Konserwatyści i Reformatorzy \\
\hline $\begin{array}{l}\text { Wiceprzewodniczący Komisji Ochrony } \\
\text { Środowiska Naturalnego, Zdrowia Publicz- } \\
\text { nego i Bezpieczeństwa Żywności }\end{array}$ & \multirow{2}{*}{ Bogusław Sonik } & \multirow[t]{2}{*}{$\begin{array}{l}\text { Grupa Europejskiej Partii Ludowej (Chrześ- } \\
\text { cijańscy Demokraci) }\end{array}$} \\
\hline $\begin{array}{l}\text { Wiceprzewodniczący Komisji Kontroli Bu- } \\
\text { dżetowej }\end{array}$ & & \\
\hline $\begin{array}{l}\text { Wiceprzewodniczący Komisji Handlu Mię- } \\
\text { dzynarodowego }\end{array}$ & Paweł Zalewski & $\begin{array}{l}\text { Grupa Europejskiej Partii Ludowej (Chrześ- } \\
\text { cijańscy Demokraci) }\end{array}$ \\
\hline $\begin{array}{l}\text { Wiceprzewodniczący Komisji Spraw Kon- } \\
\text { stytucyjnych }\end{array}$ & Rafał Trzaskowski & $\begin{array}{l}\text { Grupa Europejskiej Partii Ludowej (Chrześ- } \\
\text { cijańscy Demokraci) }\end{array}$ \\
\hline $\begin{array}{l}\text { Wiceprzewodniczący specjalnej Komisji } \\
\text { ds. Wyzwań Politycznych }\end{array}$ & Jan Olbrycht & $\begin{array}{l}\text { Grupa Europejskiej Partii Ludowej (Chrześ- } \\
\text { cijańscy Demokraci) }\end{array}$ \\
\hline Kwestor PE & $\begin{array}{l}\text { Lidia Geringer de } \\
\text { Oedenberg }\end{array}$ & $\begin{array}{l}\text { Grupa Postępowego Sojuszu Socjalistów } \\
\text { i Demokratów }\end{array}$ \\
\hline Kwestor PE & Bogusław Liberadzki & $\begin{array}{l}\text { Grupa Postępowego Sojuszu Socjalistów } \\
\text { i Demokratów }\end{array}$ \\
\hline
\end{tabular}

Źródło: Opracowanie własne na podstawie danych podanych w Komunikacie prasowym, Polacy na stanowiskach w Parlamencie Europejskim, Dział Prasowy, Dyrekcja ds. Kontaktów z Mediami, Instytucje - Polska - 1.02.2007, na oficjalnych stronach internetowych Parlamentu Europejskiego, http:/www.europarl.europa.eu/sides/getDoc.do?pubRef=-//EP//NONSGML+IM-PRESS+20070109IPR01815+PL+DOC+PDF+V0//PL\&language=PL, 24.04.2014.

Jak wyżej wspomniano, od stycznia 2012 r. czterej polscy europosłowie, będący wcześniej członkami grupy (EKR), utworzyli nową grupę pod nazwą Europa Wolności i Demokracji Bezpośredniej (EFD). Jacek Kurski został jej wiceprzewodniczącym.

$\mathrm{Z}$ dziewięciu do siedmiu mandatów zmniejszyła się delegacja polska w grupie Postępowego Sojuszu Socjalistów i Demokratów (S\&D).

Powyżej opisany sposób zorganizowania pracy polskich europosłów VII kadencji PE wskazuje na zdecydowane zgrupowanie sił początkowo w trzech, a następnie w czterech grupach politycznych, co ilustruje tabela 1 .

O ile stanowiska lidera grupy politycznej czy Przewodniczącego PE, które Polacy sprawowali w I połowie kadencji, pozwalają na uczestnictwo w Konferencji Przewodniczących, to w II połowie kadencji polska delegacja tracąc przewodnictwo w Parla- 
mencie pozwoliła na utratę pozycji lidera w grupie politycznej i nie zdobyła szefostwa w żadnej innej. W ten sposób Polacy nie brali bezpośredniego udziału w rozmowach dotyczących polityki i legislacji.

Z pewnością brak polskiej reprezentacji w Konferencji Przewodniczących był decydującym czynnikiem przy obsadzie komisji parlamentarnych. Na 20 stałych komisji Polacy otrzymali ważne jedno stanowisko przewodniczącego Komisji Rozwoju Regionalnego. Została nim Danuta Hübner z ramienia grupy EPL. Jak wcześniej wskazano, silna pozycja polskiej delegacji w tej grupie politycznej potwierdza wstępne założenie, że przynależność do dużej grupy w PE sprzyja obsadzie stanowisk politycznych. Posłanka pełniła tę funkcję przez całą kadencję. Ponadto komisja ta była istotna z polskiego punktu widzenia, bowiem współuczestniczy w legislacji dotyczącej podziału unijnych funduszy.

Ponadto w I połowie kadencji pięciu Polaków pełniło funkcję wiceprzewodniczących komisji parlamentarnych: Bogusław Liberadzki - w Komisji Kontroli Budżetowej (CONT), Janusz Wojciechowski - w Komisji Rolnictwa i Rozwoju Wsi (AGRI), Bogusław Sonik - w Komisji Ochrony Środowiska Naturalnego, Zdrowia Publicznego i Bezpieczeństwa Żywności (ENVI), Paweł Zalewski - w Komisji Handlu Międzynarodowego (INTA) oraz Rafał Trzaskowski - w Komisji Spraw Konstytucyjnych (AFCO).

Podobnie w II połowie kadencji pięciu Polaków pełniło stanowiska wiceprzewodniczących. Byli nimi: Bogusław Liberadzki - w Komisji Kontroli Budżetowej (CONT), Bogusław Sonik - w Komisji Kontroli Budżetowej (CONT), Janusz Wojciechowski - w Komisji Rolnictwa i Rozwoju Wsi (AGRI), Czesław Siekierski - w Komisji Rolnictwa i Rozwoju Wsi (AGRI) oraz Paweł Zalewski - w Komisji Handlu Międzynarodowego (INTA).

Istotny dla przedmiotowej analizy jest udział polskich europosłów w pracach merytorycznych komisji parlamentarnych. Liczną reprezentację mieliśmy w następujących wybranych komisjach, które są znaczące dla unijnego procesu decyzyjnego: dziesięciu przedstawicieli pracowało w Komisji Rozwoju Regionalnego (REGI); po sześciu w komisjach Ochrony Środowiska Naturalnego, Zdrowia Publicznego i Bezpieczeństwa Żywności (ENVI), Wolności Obywatelskich, Sprawiedliwości i Spraw Wewnętrznych (LIBE) oraz Transportu i Turystyki (TRAN); siedmiu w komisji Rolnictwa i Rozwoju Wsi (AGRI); oraz trzech w komisji Rybołówstwa (PECH) (Warso, 2013, s. 4).

Najliczniejszą reprezentację - aż piętnaścioro polskich reprezentantów - mieliśmy w Komisji Spraw Zagranicznych (AFET). Lecz jak na wstępie zaznaczono, zgodnie $\mathrm{z}$ traktatowym podziałem kompetencji, sprawy zagraniczne pozostają w wyłącznej kompetencji państw członkowskich i Parlament Europejski ma w tej dziedzinie bardzo ograniczone uprawnienia wysłuchania i ewentualnie udzielania zaleceń. Do komisji o mniejszym znaczeniu legislacyjnym, w których kompetencje Parlamentu są węższe i mogą ograniczać się do konsultacji, należy zaliczyć jeszcze: komisję Handlu Międzynarodowego (INTA), w której mieliśmy czterech reprezentantów oraz komisję Przemysłu, Badań naukowych i Energii (ITRE), gdzie pracowało dziewięciu polskich europarlamentarzystów (Warso, 2013, s. 4).

Analizy kolejnych danych dotyczących obsady stanowisk i ważnych funkcji w PE potwierdzają wniosek, że ukształtował się trend do kreowania silnej polityki zagranicz- 
nej Unii Europejskiej, zwłaszcza w jej kierunku wschodnim, poprzez pracę parlamentarną. Paweł Kowal (EKR) był przewodniczącym Delegacji do współpracy z Ukrainą, Filip Kaczmarek (EPL) z Białorusią, a Jacek Saryusz-Wolski (EPL) oraz Ryszard Czarnecki (EKR) pełnili funkcje wiceprzewodniczących Delegacji do Zgromadzenia Parlamentarnego Euronest, powołanej w związku z Partnerstwem Wschodnim.

W VII kadencji PE polscy europosłowie pełnili łącznie 102 razy funkcję posła sprawozdawcy $^{14}$. Jak już wyjaśniono na wstępnie nie wszystkie sprawozdania mają takie same znaczenie dla procesu decyzyjnego, stąd istotne w analizie są sprawozdania przygotowywane w procedurze kodecyzji. Wymagają one specjalistycznej wiedzy i umiejętności negocjacyjnych, a Parlament ma rzeczywisty wpływ na tworzone prawo. W Komisji Rozwoju Regionalnego (REGI), w której pracowało najwięcej polskich eurodeputowanych z ramienia grupy EPL przygotowano 5 sprawozdań ${ }^{15}$. Inną komisją, w której zasiadało dużo polskich przedstawicieli to Komisja Rolnictwa i Rozwoju Wsi (AGRI), w której przygotowano 5 sprawozdań z ramienia grupy EKR oraz 2 z EPL (Warso, 2013, s. 8). Naturalnie jest to niewielki odsetek sprawozdań. Najwięcej przygotowano w Komisji Prawnej (JURI) - 10 z grupy EPL, 14 S\&D oraz 1 EWD. Podobnie dużą liczbę sprawozdań przygotowano jeszcze w Komisji Budżetu (BUDG) - 12 z grupy EPL, 2 z grupy S\&D oraz 10 z EKR (Warso, 2013, s. 8).

\section{Wnioski}

W oparciu o przyjęte w Parlamencie zasady jego funkcjonowania autorka wyodrębniła działania służące zwiększeniu skali wpływu w grupie politycznej, efektywności jego wykorzystania oraz skuteczności oddziaływania na decyzje unijne na przykładzie reprezentacji Polski w Parlamencie Europejskim w ciaggu minionych dziesięciu lat naszego członkostwa w Unii Europejskiej. Autorka na wstępie zdefiniowała sposób użycia mierników w badaniu. Skala wpływu została określona poprzez procentową ocenę udziału polskiej reprezentacji w grupie politycznej w PE. Efektywność wykorzystania wpływu delegacji narodowej w PE została zmierzona po pierwsze poprzez obliczenie ilości piastowanych ważnych funkcji politycznych w Parlamencie Europejskim, a po drugie poprzez ocenę, w których stałych komisjach Parlamentu Europejskiego pracowali polscy europosłowie. Miernikiem skuteczności oddziaływania polskiej reprezentacji w PE w niniejszym artykule była liczba przygotowanych sprawozdań przez polskich europosłów z wyszczególnieniem, z której grupy politycznej pochodzili, jakie funkcje piastowali i ilu Polaków uczestniczyło w pracach danej komisji merytorycznej PE. Równie ważną determinantą oceny był fakt, czy sprawozdania były przygotowywane w zwykłej procedurze ustawodawczej, w której PE może wpływać na tworzone

1429 europosłów EPL przygotowało 63 sprawozdań, siedmioro europosłów S\&D - 18 sprawozdań, natomiast posłowie mniejszościowych EKR i EWD - odpowiednio 20 i 1 sprawozdanie. Za: Z. Warso, Europarlament: instrukcja obstugi, op. cit., s. 5.

15 Trzy sprawozdania przygotowała Danuta Hübner, a dwa - Jan Olbrycht, za: Z. Warso, Europarlament: instrukcja obstugi, op. cit., s. 8. 
prawo UE - co jest warunkiem osiagnięcia skuteczności oddziaływania na decyzje unijne.

Badając skalę wpływu należy stwierdzić, że zarówno w VI, jak i w VII kadencji posłowie z ugrupowań prawicowych, którzy przystąpili do grupy Unii na Rzecz Europy Narodów (UEN) bądź Europejskich Konserwatystów i Reformatorów (EKR) osiagnęli najwięcej. Stworzyli dominującą procentowo delegację narodową w swojej grupie politycznej, która umożliwiła im w I połowie VII kadencji PE objęcie przywództwa w grupie. To oznaczało uczestnictwo polskich reprezentantów w pracach Konferencji Przewodniczących. W tym wąskim przedziale czasowym, poprzez uczestnictwo w Konferencji Przewodniczących, można oceniać wysoko skalę wpływu i efektywność jego wykorzystania. Dało to szanse na wywieranie wpływu na kierowanie pracami PE i podejmowanie strategicznych decyzji politycznych. Podsumowanie oceny efektywności zostanie dokonane poniżej.

Eurodeputowani zrzeszeni w dużych grupach politycznych, jak chadecy czy socjaliści, stanowili niższy odsetek procentowy w ramach grupy i piastowali najwyżej stanowiska wiceprzewodniczących grup. Uczestnictwo w dużej grupie oznacza narażenie na silne oddziaływanie zwiększonej rywalizacji ze strony innych delegacji narodowych. W VI kadencji posłowie PO i PSL - po początkowym entuzjazmie związanym z obecnością w największej frakcji - przekonywali się, jak trudno wpłynąć na przeforsowanie jakichkolwiek własnych projektów, a jednocześnie jak wieloma - często dramatycznymi - kompromisami jest okupione funkcjonowanie w ramach wielonarodowościowego, wielonurtowego kolosa (Libicki, 2008).

Mimo, iż skala wpływu licznej delegacji narodowej w małej grupie politycznej może być wysoka, to nie osiaga ona w długim okresie znacznych efektów. W II połowie VI kadencji PE najliczniejszą polską reprezentacją w PE była w liczbie 20 osób eurosceptyczna delegacja w Unii na Rzecz Europy Narodów (UEN). Będąc najliczniejszą delegacją narodową w grupie uzyskała stanowisko Wiceprzewodniczącego PE oraz przewodniczącego komisji. Zestawiając efekty uzyskane przez porównywalne ilości polskich reprezentantów zrzeszonych w grupie EPL-ED należy wskazać, że eurodeputowani z dużej grupy politycznej piastowali więcej stanowisk politycznych (patrz tabela 4).

Stąd należy stwierdzić, że w badaniu pozytywnie zweryfikowano przyjętą hipotezę, że przynależność do liczącej się, dużej grupy politycznej PE zwiększa efektywność i skuteczność oddziaływania.

W VI kadencji PE początkowo 19, a w II połowie kadencji o czterech mniej, polskich eurodeputowanych przynależało do największej grupy politycznej EPL-ED. Spośród nich jedna osoba pełniła funkcję Wiceprzewodniczącego PE, dwie były przewodniczącymi komisji oraz trzy pełniły łącznie pięć razy funkcję wiceprzewodniczących komisji. Natomiast w VII kadencji eurodeputowani zrzeszeni w grupie EPL pełnili funkcje: Przewodniczącego PE, Wiceprzewodniczącego PE, dwa razy przewodniczącego komisji oraz sześć razy wiceprzewodniczącego komisji. Powyższy przykład jednocześnie ilustruje podniesienie skali wpływu reprezentantów Polski skupionych w tej grupie politycznej, bowiem w drugiej badanej kadencji ich liczebność uległa niemal podwojeniu i uzyskaliśmy ważniejsze politycznie stanowiska. Przewodniczący PE kieruje bowiem pracami Konferencji Przewodniczących. 
Zatem hipoteza o efektywności wpływu na decyzje unijne, wynikającej z przynależności do dużej grupy politycznej w PE, została w badaniu potwierdzona. Wiąże się ona z możliwością obejmowania stanowisk i tym samym przyczyniania się do zwiększania skuteczności oddziaływania polskiej reprezentacji w PE. Powiększenie skali wpływu, czyli zwiększenie liczebności polskiej delegacji w ramach grupy, istotnie wpłynęło na pozyskanie kluczowych stanowisk w Parlamencie. Dopiero dzięki zastosowaniu triangulacji widoczne jest, że uczestnictwo w dużej grupie politycznej liczącą się delegacją narodową daje pożądany efekt, którym jest możliwość ubiegania się o najważniejsze stanowiska polityczne w Parlamencie.

Badanie wykazało, że efektywność prowadzonej polityki zależy w dużej mierze od tego, której grupy politycznej w PE jest się członkiem. W obydwu analizowanych kadencjach Parlamentu największe wpływy uzyskali ci eurodeputowani, którzy przystapili do najliczniejszych grup w PE (patrz tab. 4). Mogli ubiegać się o ważne stanowiska polityczne w PE, o funkcję posła sprawozdawcy i koncentrować na udziale w procesie legislacyjnym (Miecznikowska, 2010, s. 71).

Zestawienie stanowisk objętych przez Polaków w Parlamencie Europejskim VI (2004-2009) i VII kadencji (2009-2014)

\begin{tabular}{|c|c|c|c|c|}
\hline \multirow{2}{*}{$\begin{array}{l}\text { Pelniona funkcja } \\
\text { Przewodniczący PE }\end{array}$} & \multicolumn{2}{|c|}{ VI kadencja PE } & \multicolumn{2}{|c|}{ VII kadencja PE } \\
\hline & - & - & 1 (EPL) & - \\
\hline Wiceprzewodniczący PE & $\begin{array}{l}1 \text { (EPL-ED) } \\
1 \text { (ALDE) } \\
\end{array}$ & $\begin{array}{l}1 \text { (UEN) } \\
1 \text { (PES) } \\
\end{array}$ & - & 1 (EPL) \\
\hline Przewodniczący komisji & $\begin{array}{l}1 \text { (EPL-ED) } \\
1 \text { (UEN) } \\
\end{array}$ & \begin{tabular}{|l|}
1 (EPL-ED) \\
1 (UEN) \\
\end{tabular} & 1 (EPL) & 1 (EPL) \\
\hline Wiceprzewodniczący komisji & $\begin{array}{l}2 \text { (EPL-ED) } \\
1 \text { (PES) } \\
1(\mathrm{NI})\end{array}$ & $\begin{array}{l}1 \text { (EPL-ED) } \\
2 \text { (PES) } \\
1 \text { (ALDE) } \\
1 \text { (UEN) }\end{array}$ & $\begin{array}{l}3 \text { (EPL) } \\
1 \text { (PES) } \\
1 \text { (EKR) }\end{array}$ & $\begin{array}{l}3 \text { (EPL) } \\
1 \text { (PES) } \\
1 \text { (EKR) }\end{array}$ \\
\hline
\end{tabular}

Źródło: Opracowanie własne na podstawie danych podanych w Komunikacie prasowym, Polacy na stanowiskach w Parlamencie Europejskim, Dział Prasowy, Dyrekcja ds. Kontaktów z Mediami, Instytucje - Polska - 1.02.2007, na oficjalnych stronach internetowych Parlamentu Europejskiego, http:/www.europarl.europa.eu/sides/getDoc.do?pubRef=-//EP//NONSGML+IM-PRESS+20070109IPR01815+PL+DOC+PDF+V0//PL\&language=PL, 24.04.2014.

Widoczna jest różnica w sposobie zorganizowania pracy europosłów w kadencji VI, gdzie występowało większe rozproszenie polskiej delegacji. Dopiero w II połowie kadencji zorganizowanie eurodeputowanych wokół UEN w taki sposób, że stanowili pierwszą siłę w jej szeregach, wzmocniło pozycję Polaków w PE. Do zarzutu rozdrobnienia grupy narodowej w VI kadencji można dołączyć jeszcze argument, że eurodeputowani przyłączyli się do grup politycznych znajdujących się poza głównym nurtem polityki, co było znaczącym utrudnieniem dla realizacji polskiego interesu i toczenia rozgrywek politycznych. Natomiast w kadencji VII widoczna jest silna reprezentacja delegacji polskiej w grupie EPL oraz EKR (patrz tabela 1).

Badaniu podlegał także wybór komisji parlamentarnych dokonywany przez polskich eurodeputowanych pod względem zakresu kompetencji przysługujących Parlamentowi, który przesądzał o efektywności podejmowanych działań. W badaniu istotne 
było, czy opiniowane przez komisję akty przechodzą w trybie zwykłej procedury ustawodawczej, dającej Parlamentowi decydujący wpływ na ich treść. $Z$ analizy wynika, że polska delegacja nie kierowała się tym kryterium, lecz raczej tematyką nośną medialnie, czyli głównie: polityką zagraniczną, budżetem, funduszami europejskimi, a w następnej kadencji doszły jeszcze tematy energii i środowiska.

W celu podsumowania skuteczności oddziaływania polskiej delegacji skupionej w EPL analizowano pracę merytoryczną w komisjach w oparciu o sprawozdania. W VI kadencji PE pod względem ilościowym 4/5 wszystkich sprawozdań przygotowali eurodeputowani z grupy EPL-ED. Wśród sprawozdań przygotowanych w procedurach kodecyzji także przeważają przygotowane przez członków tej grupy politycznej. W zestawieniu z VII kadencją, w której wzrosła liczba przygotowanych sprawozdań, nasuwa się jeszcze jeden wniosek. Dzięki pełnieniu funkcji posła sprawozdawcy rośnie renoma i prestiż, czego dowodem są: Janusz Lewandowski, Jerzy Buzek na forum europejskim oraz przykładowo Barbara Kudrycka i Rafał Trzaskowski na forum krajowym. Mimo wzrostu ogólnej liczby złożonych sprawozdań, doświadczenia oraz liczebności delegacji polskiej w analizowanej grupie politycznej spadła łączna ilość sprawozdań przygotowanych przez polskich eurodeputowanych z grupy EPL do 3/5.

Znaczną ilość sprawozdań w VII kadencji PE przygotowała liczna polska reprezentacja z grupy politycznej EKR. Dokonała tego w komisjach, w których dominowali polscy eurodeputowani. Po pierwsze w Komisji Rolnictwa i Rozwoju Wsi (AGRI), w której Polacy mieli dwóch wiceprzewodniczących, w tym jednego z tego ugrupowania - Janusza Wojciechowskiego. Po drugie stało się to także w Komisji Budżetu (BUDG), gdzie mieliśmy także dwóch wiceprzewodniczących z EPL oraz PES.

Analiza składu komisji parlamentarnych oraz ilości przygotowanych sprawozdań wybija jednak na pierwszy plan inne wnioski. Widoczne było znaczące zaangażowanie polskich posłów VI kadencji Parlamentu Europejskiego w działaniach poszczególnych grup politycznych, pracach w podkomisjach oraz uczestnictwo w delegacjach na rzecz kreowania nowej, aktywnej polityki UE wobec Europy Wschodniej i państw z tzw. obszaru poradzieckiego (Sprawozdanie, 2010, s. 160 i nast.). Polscy posłowie dbali m.in. o zainteresowanie Ukrainą na forum PE i o zachowanie perspektywy jej członkostwa. Jednocześnie ta swoista specjalizacja Polski ograniczała skuteczność oddziaływania na politykę PE w dziedzinie rozszerzania UE. Polscy posłowie, koncentrując się na wschodnich sąsiadach UE, tracili poparcie dla swoich inicjatyw, zwłaszcza tych deputowanych, którzy wspierali aspiracje państw bałkańskich oraz Turcji (Sprawozdanie, 2010, s. 159).

Do problematyki polityki zagranicznej podejmowanej przez polską reprezentację w VI kadencji dołączono w VII kadencji PE inne działania, równie ważne z punktu widzenia polskich interesów, takie jak: sprawy budżetowe autorstwa Sidonii Jędrzejewskiej (EPL), politykę rybołówstwa - Jarosława Wałęsy (EPL) oraz przykładowo strategię UE na rzecz regionu Morza Bałtyckiego - Wojciecha Olejniczaka (PES).

Po drugie z pogłębionej analizy dotyczącej składania sprawozdań wynika, że tylko część polskich eurodeputowanych zaistniała na forum komisji i stała się ekspertami w wybranych dziedzinach, specjalizując się i otrzymując częściej funkcję posła sprawozdawcy w konkretnym temacie. $Z$ licznej polskiej delegacji narodowej jest to ok. jedna trzecia posłów, którzy pełnili tę funkcję (Szczepanik, Kucharczyk, s. 10). Analizy 
poczynione w niniejszym artykule dotyczące obydwu kadencji potwierdzają że dużą rolę $\mathrm{w}$ przydzielaniu sprawozdań odgrywa dostęp do prezydium komisji. Zarówno w VI, jak i w VII kadencji często funkcję sprawozdawcy pełniły osoby będące przewodniczącym lub wiceprzewodniczącym komisji. Efektywność tych eurodeputowanych i skuteczność oddziaływania była wyższa w przypadkach wysokiej skali wpływu delegacji narodowej w komisji. Potwierdza to wstępne założenie o istotnej roli skali wpływu i efektywności dla uzyskania skuteczności oddziaływania.

Z kolei posłowie PiS, PJN i SP - mający nieco mniejszy wpływ na parlamentarne negocjacje $\mathrm{z}$ uwagi na przynależność grupowa, a także będący często $\mathrm{w}$ opozycji do decyzji podejmowanych przez koalicję dużych grup, nadawali swojej działalności charakter bardziej interwencyjny, częściej zabierając głos na posiedzeniach plenarnych i formułując pytania do Komisji Europejskiej i Rady UE (Szczepanik, Kucharczyk, s. 11).

W artykule poszukiwano także odpowiedzi na pytanie, czy osiagane sukcesy są efektem sumy działań zespołowych czy gry indywidualnej. W licznych analizach autorzy podkreślaja, że na skuteczność oddziaływań polskich europosłów do PE pozytywny wpływ miało stworzenie forum dyskusyjnego w ramach tzw. Klubu Polskiego. Silną stroną aktywności polskich posłów w PE była umiejętność montowania koalicji przy wyborach władz w ramach własnej grupy politycznej i innych gremiów parlamentarnych. Polscy posłowie wykazali się dużą gotowością do współpracy przy rozstrzyganiu najważniejszych dla Polski problemów pozostających w kompetencji PE (Sprawozdanie, 2010, s. 160 i nast.).

Ważne są także inne czynniki, do których zalicza się m.in. umiejętności interpersonalne, jak umiejętność przekonywania, argumentacji, znajomość języków czy profesjonalizm, postawa konsensualno-negocjacyjna, umiejętności wyszukiwania partnerów i negocjowania, otwartość na rozwiązania satysfakcjonujące jak największą liczbę uczestników oraz jednoznaczna postawa gwarantująca realizację przyjętych ustaleń. Wymienione czynniki ułatwiają starania delegacji narodowej o to, aby grupa polityczna uwzględniła stanowisko i postulaty podczas opiniowania decyzji Rady UE. Jest to możliwe, gdy delegacja narodowa wypracuje opinię pewnego partnera negocjacji (Sprawozdanie, 2010, s. 160). Sprzyja to zachowaniu lojalności grupy politycznej podczas głosowania na posiedzeniach plenarnych Parlamentu. Sposób głosowania jest bowiem ustalany wcześniej $\mathrm{w}$ trakcie spotkań grup politycznych, w tygodniu poprzedzającym posiedzenia plenarne. Podczas tych rozmów grupy polityczne wypracowują wspólne stanowisko w określonej sprawie i przygotowują strategię wywierania wpływu na bieg wydarzeń, często stosując system tzw. whippingu ${ }^{16}$.

Nie do przecenienia jest czynnik jest dobrych relacji z pracownikami PE, którzy pracując przy komisjach i przy grupach politycznych dysponują rozbudowaną siatką nieformalnych kontaktów. Do tego należy dodać jeszcze pracowników zatrudnianych przez europejskie partie polityczne i europejskie fundacje, które przygotowują niezbędne ekspertyzy, analizy i są źródłem cennych informacji.

16 Rodzaj dyscypliny partyjnej polegającej np. na przekazywaniu instrukcji głosowania członkom grupy politycznej czy zapewnienia obecności na głosowaniach, za: S. Hix, System polityczny Unii Europejskiej, Rozdział 3 „Władza prawodawcza”, Warszawa 2010, s. 127. 
W świetle powyżej poczynionych konstatacji należy stwierdzić, że osiagnięte sukcesy są efektem połączenia działań zespołowych i umiejętności indywidualnych polskich reprezentantów w Parlamencie Europejskim. Połączenie dyspozycji jednostkowych i gry zespołowej ze znajomością obowiązujących, wewnątrzparlamentarnych reguł politycznych umożliwi maksymalizację skali wpływu oraz uzyskanie efektywności i skuteczności oddziaływania na decyzje unijne w kierunku zgodnym z polską strategią członkostwa w Unii Europejskiej.

\section{Bibliografia}

Budzanowski M. (2008), Podejmowanie decyzji w procedurze współdecydowania polskie dylematy, „Polski Przegląd Dyplomatyczny” nr 1 (41).

Diariusz Senatu RP nr 27 (2004), Kontakty międzynarodowe, Kancelaria Senatu RP, http://ww2.senat.pl/k5/dok/diar/27/2708.htm, 24.03.2014.

Giertych odwołany z funkcji przewodniczacego? (2005), „Gazeta Wyborcza” z 15 listopada 2005 roku.

Hix S. (2010), System polityczny Unii Europejskiej, Rozdział 3 „Władza prawodawcza”, Warszawa.

Nowi czlonkowie komisji w Parlamencie Europejski (2007), Komunikat prasowy, Instytucje - 31.01.2007, http://www.europarl.europa.eu/sides/getDoc.do?type=IM-PRESS\&referen$\mathrm{ce}=$ 20070130IPR02597\&language $=\mathrm{PL}$, 16.03.2014.

Polacy na stanowiskach $w$ Parlamencie Europejskim (2007), Komunikat prasowy, Dział Prasowy, Dyrekcja ds. Kontaktów z Mediami, Instytucje - Polska - 1.02.2007, oficjalne strony internetowe Parlamentu Europejskiego, http://www.europarl.europa.eu/sides/getDoc.do?type=IM-PRESS\&reference=20070109IPR01815\&secondRef=PL\&language=PL, 24.04.2014.

Libicki M. (2008), Polskie głosy i głosiki w Parlamencie Europejskim, „Gazeta Wyborcza”, 23.09.2008, http://www.pis.org.pl/article.php?id=13376, 20.03.2014.

Marmola A. (2014), Aktywność plenarna a reelekcja polskich posłów do Parlamentu Europejskiego, w: Aktywność polskich postów do Parlamentu Europejskiego kadencji 2009-2014, Raport, red. A. Olszanecka, M. Marmola, Katowice.

Miecznikowska J. (2010), Polscy postowie do PE w latach 2004-2009-ocena skuteczności i koordynacji podejmowanych dziatań, w: Rola polskich posłów do Parlamentu Europejskiego w ksztaltowaniu wybranych polityk UE (2004-2009), red. F. Gołembski, Warszawa.

Obserwatorzy Sejmu i Senatu RP w Parlamencie Europejskim V kadencji (5.05.2003-30.04.2004) (2004), Ośrodek Informacji i Dokumentacji Europejskiej, http://oide.sejm.gov.pl/oide/index.php?option=com_content\&view=article \&id=14385:obserwatorzy-sejmu-i-senatu-rp-w-parlamencie-europejskim-v-kadencji\&catid=6\&Itemid=484, 28.04.2014.

PAP (2004), z dnia 16 czerwca 2004 r.

Procedura współdecyzji i procedura pojednawcza. Przewodnik po procedurach ustawodawczych, w których Parlament Europejski działa jako współustawodawca, na mocy traktatu z Lizbony (2012), http://www.europarl.europa.eu/code/information/guide_pl.pdf, 28.03.2014.

Regulamin PE (2014), Siódma kadencja Parlamentu - luty 2014, http://www.europarl.europa.eu/sides/getDoc.do?pubRef=-//EP//TEXT+RULES-EP+20140203+TOC+DOC+XML+V0//PL\&language $=$ PL, 28.04.2014.

Scarrow A. (1997), Political Career Paths and the European Parliament, „Legislative Studies Quarterly", vol. 22, s. 253-263. 
Skulimowska M. (2014), Sprawozdanie nr 64/2014, Sprawozdanie nt. obsady stanowisk w Parlamencie Europejskim 2014-2019, Kancelaria Senatu RP, Przedstawiciel Kancelarii Senatu przy Unii Europejskiej, Bruksela, 8 lipca 2014 r., http://senat.gov.pl/senat-i-ue/sprawozdania-stalego-przedstawiciela-kancelarii-senatu-przy-ue/inne-sprawozdania/, 25.04.2014.

Sprawozdanie z konferencji naukowej (2010), Działalność polskich postów do Parlamentu Europejskiego - VI kadencja (2004-2009), „Przegląd Europejski”, nr 2.

Szczepanik M., Kaca E., Łada A. (2009), Bilans aktywności polskich postów do Parlamentu Europejskiego. Cele, osiagnięcia, wnioski na przyszłość, Warszawa.

Szczepanik M., Kucharczyk J. (red.) (2012), Nie tylko polityka zagraniczna. Polacy w Parlamencie Europejskim na pótmetku 7. kadencji, ISP, Warszawa, s. 11, http://www.isp.org.pl/uploads/pdf/1416294569.pdf.

Warso A. (2013), Europarlament: instrukcja obstugi, Polacy w Parlamencie Europejskim, Raport serwisu MamPrawoWiedziec.pl, s. 4, http://mamprawowiedziec.pl/file/4325, 23.04.2014.

Wyniki wedtug państw (2009), Parlament Europejski, http://www.europarl.europa.eu/aboutparlia$\mathrm{ment} / \mathrm{pl} / 00082 \mathrm{fcd} 21 /$ Results-by-country-(2009).html?tab=20, 27.04.2014.

\section{Streszczenie}

Przedmiotem niniejszego artykułu jest analiza potencjału reprezentantów Polski w Parlamencie Europejskim (PE) w okresie dziesięciu lat naszego członkostwa w Unii Europejskiej, określenie skali wpływu polskich eurodeputowanych w PE, efektywności jego wykorzystania oraz skuteczności oddziaływania na decyzje unijne. Celem jest wyjaśnienie zasad pracy i funkcjonowania PE determinujących opracowywanie strategii i realizację taktyki działania. Mechanizm działania tych zasad objaśniony zostanie na przykładzie polskiej reprezentacji w PE. Na wstępie przedstawione zostaną założenia prowadzonej analizy, metodologia oraz determinanty badania efektywności i skuteczności oddziaływania polskiej reprezentacji. Następnie w celu prowadzenia badania i weryfikacji hipotezy zostaną zanalizowane dane dotyczące kadencji VI oraz oddzielnie VII PE. Niniejsze badanie służy weryfikowaniu następującej hipotezy. Skala wpływu procentowo dużego odsetka delegacji narodowej w grupie politycznej o niewielkim znaczeniu w PE jest wysoka, ale nie przekłada się na efektywność i skuteczność oddziaływania na decyzje unijne. Większa efektywność i skuteczność reprezentacji narodowej jest w przypadku udziału procentowo niewielkiej delegacji narodowej w dużej grupie politycznej PE o dużym znaczeniu w PE.

Słowa kluczowe: Parlament Europejski, europarlamentarzyści, grupy polityczne PE, proces decyzyjny w UE

\section{Influence of Poles on EU decisions. Assessment of the efficiency and effectiveness of Polish MEPs in the sixth and the seventh terms of the European Parliament}

\section{Summary}

The paper analyses the potential of Poland's representatives in the European Parliament over the decade of Poland's membership of the European Union, determines the extent of Polish MEPs' influence in the European Parliament and assesses how efficiently and effectively this in- 
fluence was actually exercised, as reflected in the decisions made by the Union. The goal of the paper is to explain the operating principles and work of the EP which determine how its strategy is developed and tactics implemented. The mechanism of the operation of these rules will be explained on the example of Polish representation in the EP. Firstly, the foundations of the analysis, its methodology and determinants to examine the efficiency and effectiveness of the influence of Polish representation will be presented. Then, for the purpose of investigation and verification of the hypothesis, the data concerning the sixth and the seventh terms of the EP will be separately analysed. The present study is to verify the following hypothesis: the influence of a relatively large proportion of a national delegation in a political group of limited significance in the EP is high, but it does not translate into efficiency and effectiveness of the influence on Union decisions. The efficiency and effectiveness of a national representation is greater when a national delegation constitutes a relatively small percentage but participates in a large political group of great significance in the EP.

Key words: European Parliament, MEPs, political groups in the EP, decision-making process in the EU 